\title{
Biokinetics of selected heavy metals and radionuclides in the common Mediterranean echinoid Paracentrotus lividus: sea water and food exposures
}

\author{
Michel Warnau ${ }^{1,2, *}$, Jean-Louis Teyssié ${ }^{1}$, Scott W. Fowler $^{1}$ \\ ${ }^{1}$ Marine Environment Laboratory, International Atomic Energy Agency, PO Box 800, 19 av. des Castellans, \\ MC-98012 Monaco Cedex
}

${ }^{2}$ Laboratoire de Biologie Marine, CP 160-15, Université Libre de Bruxelles, 50 av. F.D. Roosevelt, B-1050 Bruxelles, Belgium

\begin{abstract}
Uptake and loss kinetics of $\mathrm{Zn}, \mathrm{Ag}, \mathrm{Cd},{ }^{134} \mathrm{Cs}$, and ${ }^{241} \mathrm{Am}$ by the echinoid Paracentrotus lividus contaminated through either water or food were determined in controlled laboratory radiotracer experiments using low contaminant concentrations. The echinoid efficiently accumulated most of the elements from water. The only exception was ${ }^{134} \mathrm{Cs}$ (concentration factor at steady state $=2.7$ ). With respect to relative metal bioavailability, concentrations in the different body compartments of $P$. lividus were generally ranked in the order: digestive wall > gonads $\geq$ body wall > Aristotle's lantern $>$ coelomic fluid. However, for ${ }^{241} \mathrm{Am}$, body wall uptake was as efficient as that of the digestive wall. The loss kinetics for $\mathrm{Zn}$, Ag, and ${ }^{134} \mathrm{Cs}$ were described by a 2 -component model whereas loss of $\mathrm{Cd}$ and ${ }^{241} \mathrm{Am}$ was linear during the time course of the experiment. Loss of the different elements was relatively slow, except for ${ }^{134} \mathrm{C}$, whose long-lived loss component was characterized by a biological half-life of $6 \mathrm{~d}$. Loss of the different elements ingested with food was described by a single-component model for $\mathrm{Cd}^{134} \mathrm{Cs}$, and Am and by a 2-component model for $\mathrm{Zn}$ and Ag. Parameters of the kinetics indicate that all (for $\mathrm{Cd}$, ${ }^{134} \mathrm{Cs}$, and ${ }^{241} \mathrm{Am}$ ) or most (for $\mathrm{Zn}$ and $\mathrm{Ag}$ ) of the ingested amount of element is readily lost from the organism with the faeces. However, estimation of the assimilated fraction of elements ingested by the echinoids suggests that food could contribute significantly to the total body burden of Ag in. P. lividus.
\end{abstract}

KEY WORDS: Metals · Radionuclides - Uptake $\cdot$ Loss $\cdot$ Paracentrotus lividus

\section{INTRODUCTION}

The usefulness of biological indicator organisms in monitoring heavy metal contamination in the marine environment has been supported by numerous studies (e.g. Haug et al. 1974, Phillips 1976. Bayne et al. 1988. Stebbing et al. 1992). Among the organisms that fulfill the criteria of biomonitor species (sensu Phillips 1976, 1990\}, mussels are those that are certainly most commonly used (see e.g. Fowler \& Oregioni 1976, Phillips 1976, Borchardt et al. 1989, O'Con-

\footnotetext{
-Address for correspondence: Laboratoire de Biologie Marine, CP 160-15, Université Libre de Bruxelles, 50 av. F.D. Roosevelt, B-1050 Bruxelles, Belgium

E-mail: mwarnau@ulb.ac.be
}

nor et al. 1994). However, an effective characterization of the contamination status of an ecosystem must rely on the use of several of these biomonitor species (Bryan 1984, Gray 1989) In addition, since mussels are not present in all ecosystems, there is a continuous need for developing the applicability of other monitor species.

The echinoid Paracentrotus lividus lives in numerous ecosystems from rocky shores to seagrass beds all around the Mediterranean and along the northeast Atlantic coasts (Hayward \& Ryland 1990). It is a key species in several of these communities, including those where the usual biomonitors (e.g. mussels) do not occur, such as in the Posidonia oceanica meadows which hold a central position in the ecology of the Mediterranean (Ott 1980, 1981, Bay 1984). In addition 
$P$ lividus is an abundant and sedentary species and is easily collected by hand or SCUBA diving; thus, it shares the general ecological requirements of a valuable candidate for biomonitoring use.

Several field surveys have investigated metal concentrations in Paracentrotus lividus. These studies have shown that this echinoid species effectively concentrates metals, and suggest that $P$. lividus could constitute a valuable biomonitor species of metal contamination in its environment (e.g. Sheppard \& Bellamy 1974, Papadopoulou et al. 1976. Augier et al. 1989, Catsiki et al. 1994, Warnau et al. 1995a, b). However, present information is limited mainly to contaminant levels, while little is known about the kinetics of metal fluxes through $P$. lividus, as is the case for echinoderms in general (Guary 1980, Miramand et al. 1982, Nakamura et al. 1986, Warnau et al. 1995c). For one metal, i.e. cadmium, it has been shown that metal bioconcentration in $P$. lividus is dose-dependent (Warnau et al. 1995c, in press).

The primary objective of the present work was to investigate the biokinetics of metal and radionuclide uptake and loss by Paracentrotus lividus in order to further assess its value as a sentinel organism for identifying and monitoring metal pollution. Contamination through both sea water and food were studied. Three heavy metals ( 1 essential, $\mathrm{Zn}$, and 2 non-essential, $\mathrm{Cd}$ and $\mathrm{Ag})$ and 2 anthropogenic radionuclides $\left({ }^{134} \mathrm{Cs}\right.$ and ${ }^{241} \mathrm{Am}$ ) of environmental concern were selected for study. Biokinetics were studied using multi-element exposures with carrier-free or high specific activity radiotracers in order to measure element fluxes at realistic contaminant concentrations (Nakamura et al. 1986, Fisher et al. 1991, Nolan \& Dahlgaard 1991, Hutchins et al. 1996).

\section{MATERIALS AND METHODS}

Sampling. The echinoid Paracentrotus lividus (Lamarck, 1816) and the phanerogam Posidonia oceanica (L.) Delile (i.e. the echinoids' main food source in the seagrass meadows: Nedelec \& Verlaque 1984) were collected in June and July 1994 by SCUBA divers between 5 and $10 \mathrm{~m}$ depth in a Posidonia oceanica meadow off 'La Pointe des Douaniers', Cap d'Ail, France. Prior to experimentation, both species were acclimated to laboratory conditions for 1 wk (constantly aerated closed circuit aquaria, salinity $38 \%$, $16.5 \pm 0.5^{\circ} \mathrm{C}, 12 \mathrm{~h}$ light: $12 \mathrm{~h}$ dark cycle).

Radiotracers and counting method. The radiotracers ${ }^{65} \mathrm{Zn}\left(\mathrm{T}_{1 / 2}=243.9 \mathrm{~d}\right.$; carrier free), ${ }^{110 \mathrm{~m}} \mathrm{Ag}\left(\mathrm{T}_{1 / 2}=249.8 \mathrm{~d}\right)$, ${ }^{109} \mathrm{Cd}\left(\mathrm{T}_{1 / 2}=462.6 \mathrm{~d}\right.$; carrier free), ${ }^{134} \mathrm{Cs}\left(\mathrm{T}_{1 / 2}=2.066 \mathrm{yr}\right)$, and ${ }^{241} \mathrm{Am}\left(\mathrm{T}_{1 / 2}=432.7 \mathrm{yr}\right)$ were purchased from Amersham, UK. Stock solutions of ${ }^{65} \mathrm{Zn},{ }^{109} \mathrm{Cd}$, and ${ }^{134} \mathrm{Cs}$ were prepared in $0.1 \mathrm{M} \mathrm{HCl}$, those of ${ }^{110 \mathrm{~m}} \mathrm{Ag}$ and ${ }^{241} \mathrm{Am}$ were maintained in $0.1 \mathrm{M} \mathrm{HNO}_{3}$.

Radioactivities were determined using a high-resolution $\gamma$-spectrometry system consisting of a coaxial Germanium $N$ type detector (EGNC 33-195-R, Intertechnique) connected to a multichannel analyser and a personal computer employing spectral analysis software (Intergamma, Intertechnique). The radioactivities of the samples were determined by comparison with known standards of appropriate geometry and were corrected for background and physical decay of the radiotracers.

Experimental procedures. Contamination of Paracentrotus lividus through sea water: Fourteen echinoids (ambital diameter mean \pm SD: $47 \pm 3 \mathrm{~mm}$ ) were placed for $28 \mathrm{~d}$ in a polyvinylchloride aquarium containing $20 \mathrm{I}$ natural sea water spiked with: ${ }^{65} \mathrm{Zn}$, $0.38 \mathrm{kBq} \mathrm{l}^{-1} ;{ }^{110 \mathrm{~m}} \mathrm{Ag}, 0.20 \mathrm{kBq} \mathrm{l^{-1 } ;}{ }^{109} \mathrm{Cd} 0.90 \mathrm{kBq} \mathrm{l^{-1 }}$; ${ }^{134} \mathrm{Cs}, 0.57 \mathrm{kBq}^{-1}$; and ${ }^{241} \mathrm{Am}, 0.28 \mathrm{kBq}^{-1}$. In terms of metal additions, these activities correspond to $1.2 \mathrm{pg}$ $\mathrm{Zn}, 8.5 \mathrm{ng} \mathrm{Ag}, 9 \mathrm{pg} \mathrm{Cd}, 1.3 \mathrm{ng} \mathrm{Cs}$, and $2.2 \mathrm{ng}$ Am added $1^{-1}$ sea water. Except for ${ }^{241} \mathrm{Am}$, which has no stable element, additions of metal were approximately 1 to 5 orders of magnitude lower than concentrations commonly reported for natural sea water (Bruland 1983, Bryan 1984, Clark 1986). The sea water was changed and the radiotracers were renewed daily for $10 \mathrm{~d}$ and thereafter every second day. Radioactivities in the water were checked daily and before and after each seawater renewal in order to determine the time-integrated radiotracer activities (i.e. mean values of all measurements performed over the time period considered). The decreases in radioactivities in sea water between 2 successive seawater renewals differed with the radiotracer; mean decreases $( \pm \mathrm{SD}$ ) were $21 \pm 11 \%$ for ${ }^{65} \mathrm{Zn}, 31 \pm 10 \%$ for ${ }^{110 \mathrm{~m}} \mathrm{Ag}, 9 \pm 8 \%$ for ${ }^{109} \mathrm{Cd}, 4 \pm 3 \%$ for ${ }^{134} \mathrm{Cs}$, and $22 \pm 12 \%$ for ${ }^{241} \mathrm{~A} . \mathrm{m}$. For the entire experimental time course, the time-integrated radiotracer

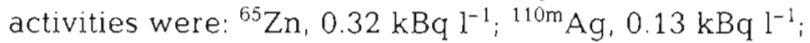
${ }^{109} \mathrm{Cd}, 0.84 \mathrm{kBq} \mathrm{l}{ }^{-1} ;{ }^{134} \mathrm{Cs}, 0.56 \mathrm{kBq} \mathrm{l}^{-1}$; and ${ }^{241} \mathrm{Am}$, $0.22 \mathrm{kBq} \mathrm{l}^{-1}$.

The echinoids were fed twice a week on leaves of Posidonia oceanica. Food was supplied in the evening (echinoids feed mainly during the night; Dance 1987. authors' pers. obs.); the next morning, the uningested food was removed from the aquarium. At different times, 6 echinoids were $\gamma$-counted to determine the radiotracer uptake kinetics. At the end of the $28 \mathrm{~d}$ exposure period, 4 echinoids were dissected. The body wall, Aristotle's lantern, digestive wall (after removal of the gut contents), gonads, and coelomic fluid were separated, weighed (wet wt), and their radiotracer contents counted.

The 10 remaining individuals were then placed for $18 \mathrm{~d}$ in clean flowing sea water (open circuit, with flux: 
$201 \mathrm{~h}^{-1}$, constantly aerated, salinity $38 \%, 16.5 \pm 0.5^{\circ} \mathrm{C}$ ). At different times, 3 echinoids were $\gamma$-counted in order to follow the radiotracer loss. After 7,14 , and $18 \mathrm{~d}$ of depuration, 3 individuals were dissected to determine the distribution of radiotracer among the different body compartments.

Counting times were adapted to obtain counting rates with relative propagated errors less than $5 \%$. Those times were $15 \mathrm{~min}$ for radioanalyses of whole echinoids and sea water, and ranged from $10 \mathrm{~min}$ to $4 \mathrm{~h}$ for the dissected body compartments

Contamination of Paracentrotus lividus through the food: Eight Posidonia oceanica shoots were exposed for $13 \mathrm{~d}$ in a polyvinylchloride aquarium containing $4 \mathrm{l}$ natural sea water spiked with: ${ }^{65} \mathrm{Zn}, 0.81 \mathrm{kBq} \mathrm{l^{-1 }}$; ${ }^{110 \mathrm{~m}} \mathrm{Ag}, 0.40 \mathrm{kBq} \mathrm{l}{ }^{-1} ;{ }^{109} \mathrm{Cd}, 1.46 \mathrm{kBq} \mathrm{l}^{-1} ;{ }^{134} \mathrm{Cs}, 1.15 \mathrm{kBq}$ $\mathrm{I}^{-1}$; and ${ }^{241} \mathrm{Am}, 0.48 \mathrm{kBq} \mathrm{l^{-1 }}$. The sea water was changed, the radiotracers were renewed, and the water radioactivities were checked daily. After $13 \mathrm{~d}$, the 8 shoots were $\gamma$-counted. All $P$. oceanica leaves used in the experiments bore epiphytes.

A 30 l polyvinylchloride aquarium copen circuit, with flux: $20 \mathrm{l} \mathrm{h}^{-1}$, constantly aerated, salinity $38 \%$, $16.5 \pm 0.5^{\circ} \mathrm{C}$ ) was divided into 2 sections (Section 1 : 25 l; Section 2: 5 l) with a $2 \mathrm{~mm}$ mesh polyethylene net which allowed sea water to flow through both parts. A group of 16 echinoids (placed in Section 1) was allowed to feed overnight ( $12 \mathrm{~h}$ feeding) on the Posidonia oceanica leaves that were previously radiolabelled. Simultaneously, a group of 4 echinoids (ambital diameter $48 \pm 3 \mathrm{~mm}$ ) was placed in Section 2 and fed uncontaminated leaves in order to serve as a control for possible contamination directly from sea water due to radiotracer leaching from the contaminated food and/or faeces. At the end of the feeding period, each echinoid exposed to contaminated food was $\gamma$-counted. Only individuals showing a detectable radioactivity (i.e. those that had effectively ingested contaminated leaves) were kept in Section 1 of the aquarium (i.e. $\mathrm{n}=5$; ambital diameter: $47 \pm 4 \mathrm{~mm}$ ). From this time onwards, all echinoids from both sections were fed ad libitum on uncontaminated leaves. Faeces were removed twice a day. At different times, the 5 echinoids contaminated via the food chain were $\gamma$-counted in order to follow radiotracer loss kinetics. The possible radioactivities occurring in the control echinoids were checked at different times. After $8 \mathrm{~d}$, all individuals were dissected to determine the distribution of radiotracer contents among the different body compartments.

Counting times were adapted to obtain counting rates with relative propagated errors lower than $5 \%$. This counting precision however could not always be reached (even after $24 \mathrm{~h}$ of counting) due to very low activity of some radiotracers at the end of the experi- ment. Counting times ranged from $15 \mathrm{~min}$ to $3 \mathrm{~h}$ for whole echinoid, sea water, and seagrass leaf radioanalyses and from 2 to $24 \mathrm{~h}$ for the dissected body compartments.

Data analyses. Uptake of the 5 radiotracers from sea water was expressed as change in concentration factors $\left(C F=\mathrm{Bq} \mathrm{g}^{-1}\right.$ wet organism divided by the timeintegrated $\mathrm{Bq} \mathrm{g^{-1 }}$ sea water) over time. Radiotracer uptake kinetics in whole echinoids were described using a single-component first-order kinetic model

$$
C F_{1}=C F_{\text {equil }}\left(1-e^{-k t}\right)
$$

where $C F_{\text {t }}$ and $C F_{\text {equil }}$ are concentration factors at time $t$ (d) and at steady state, respectively, and $k$ is the rate constant $\left(\mathrm{d}^{-1}\right)$ (Whicker \& Schultz 1982, Kuroshima et al. 1993, Brown et al. 1995j. If the observed kinetics did not tend to reach a steady state during the exposure time course, they were fitted by a simple linear regression model

$$
C F_{t}=k t
$$

where $k$ is the regression slope (i.e. rate of increase in $C F, \mathrm{~d}^{-1}$ ). Linearity of the uptake kinetics expressed as $C F$ was tested by a linearity test (1-way ANOVA) for regression with replication (Zar 1984).

Losses of the radiotracers were expressed in terms of percentage of remaining radioactivity, i.e. radioactivity at time $t$ divided by initial radioactivity measured in the organisms at the beginning of the decontamination period. The percentages of remaining activity were plotted versus time. If radiotracer losses displayed a linear form, the kinetics were described by a simple Linear model

$$
A_{1}=A_{0}-\lambda t
$$

where $A_{t}$ and $A_{0}$ are remaining activities (\%) at time $t$ (d) and 0 , respectively, and $\lambda$ is the depuration rate ( $\%$ remaining activity $\mathrm{d}^{-1}$, i.e. regression slope). Linearity was systematically tested by a linearity test for regression with replication ( $\operatorname{Zar} 1984$ ). If radiotracer losses displayed an exponential shape, the kinetics were described either by a single-component exponential model

$$
A_{1}=A_{0} \mathrm{e}^{-\lambda_{i}}
$$

where $\lambda$ is the biological depuration rate constant $\left(\mathrm{d}^{-1}\right)$ and allows the calculation of the radiotracer biological half-life $\left(T_{b 1 / 2}=\ln 2 / \lambda\right)$, or by a 2 -component exponential model

$$
A_{1}=A_{0 \mathrm{~s}} \mathrm{e}^{-\lambda_{\mathrm{s}} t}+\mathrm{A}_{0 l} \mathrm{e}^{-\lambda_{1} l}
$$

where the ' $s$ ' subscript refers to a short-lived component (s component) while the ' $\mathrm{l}$ ' subscript refers to a long-lived component (l component) (Hubbell et al. 1965, Reichle 1967, Reichle et al. 1970, Whicker \& 
Schultz 1982). The exponential model showing the best fitting accuracy (decision based on calculation of the coefficients of dertermination, $R^{2}$, and examination of the residuals) was then selected.

Considering the 2-component exponential model, the short-lived component is a model for the loss of the proportion of radiotracer pool that is weakly associated with the organism, while the long-lived component is a model of the loss of the fraction of the radiotracer pool that is tightly bound in the organism. In particular, in the case of radiotracer loss following uptake through the food, the long-lived component would be a model of the loss of the radiotracer pool fraction that is actually assimilated by the organism. Thus, the constant $A_{01}$
A. ${ }^{65} \mathrm{Zn}$

Concentration factor

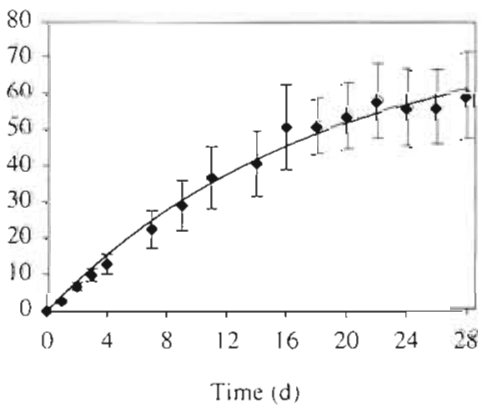

C. ${ }^{11 /} \mathrm{Cd}$

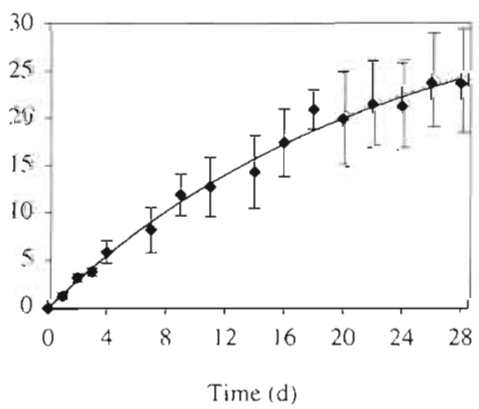

E. ${ }^{2.1} \mathrm{Am}$

Concentration factor

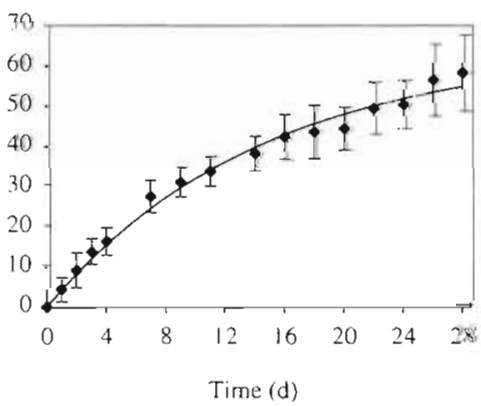

Concentration factor

is an estimate of the fraction of radioactivity assimilated from food (Reichle 1967, Fowler \& Guary 1977. Miramand et al, 1982). A biological half-life may be calculated for both short- and long-lived components $\left(\mathrm{T}_{\mathrm{b} 1 / 2 \mathrm{~s}}\right.$ and $\left.\mathrm{T}_{\mathrm{b} 1 / 21}\right)$ using the corresponding depuration rate constants ( $\lambda_{s}$ or $\lambda_{1}$, respectively) (Hubbell et al. 1965, Reichle 1967, Reichle et al. 1970, Whicker \& Schultz 1982).

Constants of the different models (both uptake and loss models) and their statistics were estimated by iterative adjustment of the models and Hessian matrix computation, respectively, using the nonlinear curvefitting routines in the Systat 5.2.1 software (Wilkinson 1988). Differences between radiotracer CF in the compartments of Paracentrotus lividus were tested by 1 -way ANOVA and the multiple comparison test of Tukey (Zar 1984). Changes in radiotracer distribution among echinoid body compartments during the depuration period were tested for significance by the $G$ procedure (adapted from the $\log$-likelihood ratio test) for $2 \times \mathrm{k}$ contingency tables (Zar 1984). The latter test was performed on arcsin-transformed data according to the correction of Freeman \& Tukey (1950) as described in Zar (1984). When considering a single body compartment, changes in \% of radioactivity during the depuration period were tested by ANOVA and Tukey's test using the arcsin-transformed data. The level of significance for statistical analyses was always set at $\alpha=0.05$

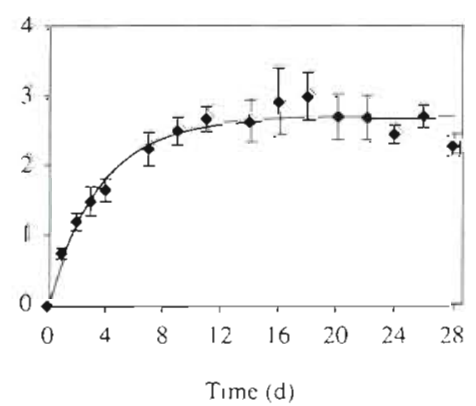

\section{RESULTS}

\section{Contamination through sea water}

The whole-body uptake of each radiotracer by Paracentrotus lividus displayed saturation kinetics except for ${ }^{110 \mathrm{~m}} \mathrm{Ag}$ (Fig. 1). However, during the time course of the experiment, only ${ }^{134} \mathrm{Cs}$ appeared to reach a steady state. The estimated steady-state concentration factors ( $C F_{\text {equil }}$ ) indicated that the elements tested were concentrated differently by $P$ lividus. In order of decreasing bioavailability, the radiotracers are ranked as follows: ${ }^{65} \mathrm{Zn}=$ ${ }^{241} \mathrm{Am}>{ }^{109} \mathrm{Cd}>{ }^{134} \mathrm{Cs}$ (Table 1).

In the case of ${ }^{110 \mathrm{~m}} \mathrm{Ag}$, the uptake kinetics were most accurately described by a linear model over the experimental time considered (Fig. 1B, Table 1). For indica-
Fig. 1 Paracentrotus lividus. Uptake from sea water of ${ }^{65} \mathrm{Zn}$, ${ }^{110 \mathrm{~m}} \mathrm{Ag},{ }^{109} \mathrm{Cd},{ }^{134} \mathrm{Cs}$, and ${ }^{241} \mathrm{Am}$ in whole echinoids (mean concentration factor $\pm \mathrm{SD}, \mathrm{n}=6$ ). Parameters of the equations fitting the data are given in Table 1 
Table 1 Paracentrotus lividus. Parameters and statistics of the equations describing the uptake kinetics of ${ }^{65} \mathrm{Zn},{ }^{110 \mathrm{~m}} \mathrm{Ag},{ }^{109} \mathrm{Cd}$, ${ }^{134} \mathrm{Cs}$, and ${ }^{241} \mathrm{Am}$ in whole echinoids exposed to the radiotracers in sea water $\mathrm{L}$ (linear uptake model): $C F_{i}=k t ; N$ (nonlinear uptake model): $C F_{t}=C F_{\text {equul }}\left(1-e^{-k i}\right) ; C F_{1}, C F_{\text {equl }}$ : concentration factors at time $t$ (d) and at steady state, respectively; $k$ : rate constant $\left(\mathrm{d}^{-1}\right)$; ASE: asymptotic standard error; $\mathrm{R}^{2}$ : determination coefficient; $\mathrm{p}$ : probability of the model adjustment

\begin{tabular}{|cccccc|}
\hline & Model & $C F_{\text {equl }}($ ASE) & $k$ (ASE) & $R^{2}$ & $p$ \\
\hline${ }^{6.5} \mathrm{Zn}$ & $\mathrm{N}$ & $77.4(6.8)$ & $0.056(0.009)$ & 0.89 & $<0.0001$ \\
${ }^{110 \mathrm{~m}} \mathrm{Ag}$ & $\mathrm{L}$ & $34.3(4.4)$ & $6.94(0.141)$ & 0.89 & $<0.0001$ \\
${ }^{109} \mathrm{Cd}$ & $\mathrm{N}$ & $2.71(0.04)$ & $0.044(0.009)$ & 0.87 & $<0.0001$ \\
${ }^{134} \mathrm{Cs}$ & $\mathrm{N}$ & $64.1(3.6)$ & $0.070(0.019)$ & 0.89 & $<0.0001$ \\
${ }^{241} \mathrm{Am}$ & $\mathrm{N}$ & & & 0.92 & $<0.0001$ \\
\hline
\end{tabular}

Table 2. Paracentrotus hvidus. Radıotracer concentration factors (mean $\pm \mathrm{SD}, \mathrm{n}=4$ ) in the different compartments of the echinoids after $28 \mathrm{~d}$ of exposure in sea water. Mean concentration factors for a given metal sharing a common superscript are not significantly different between body compartments (ANOVA and Tukey's test, $\alpha=0.05$ )

\begin{tabular}{|lcccccc|}
\hline Compartment & $\begin{array}{c}\text { \% of total echinoid } \\
\text { wet wt }\end{array}$ & ${ }^{65} \mathrm{Zn}$ & ${ }^{110 \mathrm{~m}} \mathrm{Ag}$ & ${ }^{109} \mathrm{Cd}$ & ${ }^{134} \mathrm{Cs}$ & ${ }^{241} \mathrm{Am}$ \\
\hline Body wall & $47 \pm 3.4$ & $107 \pm 19^{\mathrm{b}}$ & $377 \pm 84^{\mathrm{b}}$ & $37 \pm 8^{\mathrm{b}}$ & $2.8 \pm 0.6^{\mathrm{c}}$ & $123 \pm 20^{\mathrm{a}}$ \\
Arnstotle's lantern & $3.5 \pm 0.3$ & $75 \pm 13^{\mathrm{b}}$ & $137 \pm 47^{\mathrm{c}}$ & $18 \pm 3^{\mathrm{c}}$ & $2.4 \pm 0.6^{\mathrm{c}}$ & $23 \pm 11^{\mathrm{b}}$ \\
Digestive wall & $1.4 \pm 0.3$ & $913 \pm 174^{\mathrm{a}}$ & $1449 \pm 578^{\mathrm{d}}$ & $348 \pm 84^{\mathrm{a}}$ & $42 \pm 12^{\mathrm{d}}$ & $109 \pm 41^{\mathrm{a}}$ \\
Gonads & $2.1 \pm 1.4$ & $97 \pm 22^{\mathrm{b}}$ & $445 \pm 238^{\mathrm{b}}$ & $29 \pm 8^{\mathrm{b}}$ & $5.3 \pm 1.8^{\mathrm{b}}$ & $9^{\mathrm{b}} \pm 4.1^{\mathrm{c}}$ \\
Coelomic fluid & $46 \pm 4.7$ & $3.4 \pm 0.9^{\mathrm{c}}$ & $11 \pm 11^{\mathrm{d}}$ & $3.5 \pm 1.9^{\mathrm{d}}$ & $0.7^{\mathrm{d}} \pm 0.1^{\mathrm{d}}$ & $0.4 \pm 0.2^{\mathrm{d}}$ \\
\hline
\end{tabular}

tive information, the saturation model was tentatively applied to ${ }^{110 \mathrm{~m}} \mathrm{Ag}$ uptake. Adjustment of the model to those data suggests that a $C F_{\text {equil }}=604 \pm 166$ (mean \pm asymptotic standard error) would be reached with a rate constant $k=0.0132 \pm 0.004 \mathrm{~d}^{-1}$

Radiotracer $C F$ in the different body compartments of Paracentrotus lividus were calculated after $28 \mathrm{~d}$ of exposure (Table 2). The digestive wall concentrated ${ }^{65} \mathrm{Zn},{ }^{110 m} \mathrm{Ag},{ }^{109} \mathrm{Cd}$, and ${ }^{134} \mathrm{Cs}$ to the greatest degree (Tukey's test, $p \leq 0.001$ ), i.e. up to 1 order of magnitude greater than in the body wall and/or the gonads. ${ }^{241} \mathrm{Am}$ was concentrated to a similar degree in the digestive wall and in the body wall (Tukey's test, $p=0.88$ ).

In terms of total radioactivity distribution between the body compartments (taking into account the weighted contribution of each compartment), the body wall always contained the highest proportion of radiotracer (from 50 to $95 \%$, according to the considered element; Table 3A), followed by the digestive wall which contained 3 to $28 \%$ of the total radioactivity.

After a 28 d exposure, the echinoids were maintained for $18 \mathrm{~d}$ in uncontaminated sea water to follow radiotracer loss kinetics. Loss of ${ }^{109} \mathrm{Cd}$ and ${ }^{241} \mathrm{Am}$ was most accurately described by simple linear models (Fig. 2C, E, Table 4). Assuming the loss would continue at this rate beyond the experimental time course, complete depuration of accumulated ${ }^{109} \mathrm{Cd}$ and ${ }^{241} \mathrm{Am}$ would occur after 130 and 43 d, respectively. Loss kinetics for the other 3 radiotracers $\left({ }^{65} \mathrm{Zn},{ }^{110 m} \mathrm{Ag}\right.$, and
${ }^{134} \mathrm{Cs}$ ) were best described by 2 -component exponential models (Fig. 2A, B, D, Table 4). The short-lived loss components were characterized by very short biological half-lives, ranging from 8 to $23 \mathrm{~h}$ (Table 4). The long-lived loss components represented a large proportion of the total radioactivity $\left(A_{0}\right)$ from 64 to $91 \%$ ) and, except for ${ }^{134} \mathrm{Cs}$, were characterized by an estimated $T_{b 1 / 21}$ of the order of 2 mo ( 46 to $86 \mathrm{~d}$ ). In the case of ${ }^{134} \mathrm{Cs}$, the estimated $T_{b 1 / 21}$ was $6.5 \mathrm{~d}$.

The distribution of radiotracer activity among the Paracentrotus lividus body compartments was determined after 7 and $14 \mathrm{~d}$ of depuration in uncontaminated sea water (Table 3B, C). (Due to mortality of 2 echinoids in the aquarium on Day 17, determination of body distribution of the radiotracers as planned for Day 18 could be carried out for only 1 individual. The data set for this single individual is similar to the distribution reported for Day 14 in Table $3 \mathrm{C}$ for 3 individuals.)

Comparison of the radiotracer distributions at the end of the exposure period (Table $3 \mathrm{~A}$ ) with those calculated during the depuration period (Table $3 \mathrm{~B}, \mathrm{C}$ ) indicates that the relative tissue distribution of ${ }^{241} \mathrm{Am}$ in echinoids remained constant throughout the experiment ( $G$ test, $p>0.50$ ). This suggests that ${ }^{241} \mathrm{Am}$ loss from the different echinoid body compartments occurs at similar rates. The same appears to be generally valid for ${ }^{109} \mathrm{Cd}$, though the distribution of this element at the end of the exposure period is significantly different from its distribution after $14 \mathrm{~d}$ of 
Table 3. Paracentrotus lividus. Radiotracer distribution (mean \% \pm SD) between the different body compartments of the echinoids exposed to the radiotracers in sea water

\begin{tabular}{|c|c|c|c|c|c|}
\hline Compartment & ${ }^{65} \mathrm{Zn}$ & $110 \mathrm{~m} \mathrm{Ag}$ & ${ }^{109} \mathrm{Cd}$ & ${ }^{134} \mathrm{Cs}$ & ${ }^{241} \mathrm{Am}$ \\
\hline \multicolumn{6}{|c|}{ (A) At the end of the exposure period $(28$ d) $(n=4)$} \\
\hline Body wall & $70.0 \pm 2.9$ & $79.9 \pm 9.0$ & $66.2 \pm 2.6$ & $51.6 \pm 5.9$ & $95.0 \pm 1.6$ \\
\hline Aristotle's lantern & $3.5 \pm 1.0$ & $2.1 \pm 0.8$ & $2.3 \pm 0.6$ & $3.2 \pm 0.5$ & $1.3 \pm 0.6$ \\
\hline Digestive wall & $21.7 \pm 2.1$ & $11.9 \pm 6.2$ & $23.0 \pm 6.1$ & $28.3 \pm 5.7$ & $3.1 \pm 1.1$ \\
\hline Gonads & $2.6 \pm 0.7$ & $3.9 \pm 1.8$ & $2.2 \pm 0.7$ & $4.0 \pm 1.1$ & $0.3 \pm 0.1$ \\
\hline Coelomic fluid & $2.1 \pm 0.5$ & $2.3 \pm 2.3$ & $6.2 \pm 3.4$ & $12.9 \pm 0.8$ & $0.3 \pm 0.1$ \\
\hline \multicolumn{6}{|c|}{ (B) Aiter $7 \mathrm{~d}$ in uncontaminated sea water $(\mathrm{n}=3)$} \\
\hline Body wall & $45.1 \pm 4.4$ & $52.5 \pm 8.1$ & $68.3 \pm 4.6$ & $52.5 \pm 14.0$ & $93.7 \pm 2.4$ \\
\hline Aristotle's lantern & $6.0 \pm 0.6$ & $5.0 \pm 2.6$ & $3.0 \pm 0.3$ & $9.0 \pm 6.1$ & $2.0 \pm 0.4$ \\
\hline Digestive wall & $38.8 \pm 6.8$ & $25.1 \pm 2.2$ & $22.5 \pm 3.0$ & $17.4 \pm 12.0$ & $3.2 \pm 2.4$ \\
\hline Gonads & $6.7 \pm 5.1$ & $8.3 \pm 6.9$ & $4.5 \pm 3.9$ & $16.5 \pm 20.0$ & $0.5 \pm 0.3$ \\
\hline Coelomic fluid & $3.4 \pm 0.8$ & $9.1 \pm 4.8$ & $1.8 \pm 1.7$ & $4.5 \pm 1.8$ & $0.5 \pm 0.1$ \\
\hline \multicolumn{6}{|c|}{ (C) After $14 \mathrm{~d}$ in uncontaminated sea water $(\mathrm{n}=3$ ) } \\
\hline Body wall & $51.5 \pm 5.0$ & $43.1 \pm 4.9$ & $65.7 \pm 5.8$ & $31.0 \pm 20.6$ & $95.5 \pm 0.2$ \\
\hline Aristotle's Iantern & $6.2 \pm 1.4$ & $3.3 \pm 0.1$ & $3.0 \pm 0.4$ & $9.9 \pm 7.1$ & $1.3 \pm 0.2$ \\
\hline Digestive wall & $2.3 .4 \pm 2.5$ & $28.1 \pm 5.6$ & $20.9 \pm 6.1$ & $29.6 \pm 1.8$ & $2.0 \pm 0.5$ \\
\hline Gonads & $14.9 \pm 2.3$ & $16.6 \pm 3.3$ & $8.9 \pm 0.8$ & $22.1 \pm 7.9$ & $0.9 \pm 0.5$ \\
\hline Coelomic fluid & $4.0 \pm 0.4$ & $8.9 \pm 2.1$ & $1.4 \pm 0.6$ & $7.4 \pm 4.5$ & $0.4 \pm 0.2$ \\
\hline
\end{tabular}

Table 4. Paracentrotus lividus. Parameters and statistics of the equations describing the loss kinetics of ${ }^{65} \mathrm{Zn},{ }^{110 m} \mathrm{Ag},{ }^{109} \mathrm{Cd},{ }^{134} \mathrm{Cs}$, and ${ }^{241} \mathrm{Am}$ in whole echinoids previously exposed for $28 \mathrm{~d}$ to radiotracers in sea water $\mathrm{L}$ (linear loss model): $A_{t}=A_{0}-\lambda t ;$ $\mathrm{T}$ (2-component loss model): $A_{t}=A_{0}, \mathrm{e}^{-\lambda_{s} t}+A_{01} \mathrm{e}^{-\lambda_{1} l} ; A_{1} A_{0}$ : remaining activities (\%) at time $t$ (d) and 0 , respectively; $\lambda$ : depuration rate constant $\left(\mathrm{d}^{-1}\right)_{i} \mathrm{~T}_{\mathrm{b} 1 / 2}$ : biological half-life $(\mathrm{d})$; s and I subscripts: relative to short-and long-term component, respectively; other symbols as in Table 1

\begin{tabular}{|c|c|c|c|c|c|c|c|c|c|}
\hline & Model & $A_{0 \mathrm{~S}}(\mathrm{ASE})$ & $\lambda_{s}(\mathrm{ASE})$ & $T_{b 1 / 2 \mathrm{~s}}$ & $A_{0 !}(\mathrm{ASE})$ & $\lambda_{1}(\mathrm{ASE})$ & $T_{b 1 / 21}$ & $\mathrm{R}^{2}$ & $\mathrm{p}$ \\
\hline${ }^{65} \mathrm{Zn}$ & $\mathrm{T}$ & $12.8(6.5)$ & $0.713(0.626)$ & 0.97 & $87.8(5.6)$ & $0.008(0.006)$ & 86 & 0.61 & $<0.0001$ \\
\hline $110 \mathrm{~m} A g$ & $\mathrm{~T}$ & $8.9(4.8)$ & $2.036(3.353)$ & 0.34 & $91.1(3.3)$ & $0.015(0.004)$ & 46 & 0.69 & $<0.0001$ \\
\hline${ }^{109} \mathrm{Cd}$ & $\mathrm{L}$ & $98.9(1.6)$ & $0.760(0.202)$ & - & & & & 0.39 & 0.001 .1 \\
\hline${ }^{134} \mathrm{Cs}$ & $\mathrm{T}$ & $36.1(12.8)$ & $1.184(0.838)$ & 0.59 & $63.7(12.6)$ & $0.106(0.026)$ & 6.5 & 0.95 & $<0.0001$ \\
\hline${ }^{241} \mathrm{Am}$ & $\mathrm{L}$ & $99.0(1.0)$ & $2.297(0.119)$ & - & & & & 0.94 & $<0.0001$ \\
\hline
\end{tabular}

depuration ( $\mathrm{G}$ test, $\mathrm{p}=0.05$ ). However, the significance of this difference is not great and is due to the gonads, whose \% of radioactive ${ }^{109} \mathrm{Cd}$ increased significantly during the depuration period (ANOVA, $p=0.019$ ). This observation suggests that gonads retain cadmium somewhat more efficiently than the other body compartments.

For ${ }^{65} \mathrm{Zn},{ }^{110 \mathrm{~m}} \mathrm{Ag}$, and ${ }^{134} \mathrm{Cs}$, the radiotracer distribution among echinoid body compartments calculated at the end of the exposure period is significantly different from the distribution calculated at the end of the depuration period ( $G$ test, $p<0.05$ ) (Table 3 ). The activity of those 3 radiotracers, which was essentially (50 to $80 \%$ ) contained in the body wall at the end of the exposure period, tends to be distributed more homogeneously between the body wall, the digestive wall, and the gonads following depuration. The statistically significant decrease in \% of total radioactivity occurring after depuration in the body wall (for the 3 radiotracers; ANOVA, $p \leq 0.002$ ) and the coelomic fluid (for ${ }^{134} \mathrm{Cs}$; ANOVA, $p=0.0006$ ) suggests that those compartments would retain the radiotracers less efficiently than the other body compartments.

Table 5. Radioactivity (Bq $\mathrm{g}^{-1}$ wet $w \mathrm{t}$, mean $\pm \mathrm{SD}, \mathrm{n}=8$ ) in Posidonia oceanica leaves used as radiolabelled food for echinoids and radioactivity $(\mathrm{Bq}$, range, $\mathrm{n}=5$ ) in Paracentrotus lividus fed overnight on this food

\begin{tabular}{|ccc|}
\hline Radiotracer & $\begin{array}{c}\text { Posidonia oceanica } \\
\text { (Bq g }{ }^{-1} \text { wet wt) }\end{array}$ & $\begin{array}{c}\text { Paracentrotus lividus } \\
\text { (Bq) }\end{array}$ \\
\hline${ }^{65} \mathrm{Zn}$ & $144 \pm 29$ & $8.8-66$ \\
${ }^{110 \mathrm{~m}} \mathrm{Ag}$ & $88 \pm 14$ & $5.7-56$ \\
${ }^{109} \mathrm{Cd}$ & $193 \pm 59$ & $7.6-61$ \\
${ }^{134} \mathrm{Cs}$ & $1.21 \pm 0.29$ & $0.23-1.08$ \\
${ }^{241} \mathrm{Am}$ & $99 \pm 17$ & $11-75$ \\
\hline
\end{tabular}




\section{Contamination through the food}

A radiolabelled food was prepared by exposing 8 Posidonia oceanica shoots for $13 \mathrm{~d}$ to ${ }^{65} \mathrm{Zn},{ }^{110 \mathrm{~m}} \mathrm{Ag},{ }^{109} \mathrm{Cd},{ }^{134} \mathrm{Cs}$, and ${ }^{241} \mathrm{Am}$ (Table 5). Echinoids were allowed to ingest this radiolabelled food overnight. They were then $\gamma$-counted for radiotracer contents (Table 5) and maintained in uncontaminated conditions in order to determine the loss kinetics of the elements. Examination of the control group showed that, from Day 3, contamination from sea water contributed from 3 to $11 \%$ to the ${ }^{65} \mathrm{Zn}$ and ${ }^{110 \mathrm{~m}} \mathrm{Ag}$ radioactivities measured in the experimental echinoids. This was apparently due to radiotracer leaching from faeces. The data presented in Fig. 3 have been corrected to eliminate these interferences. For ${ }^{109} \mathrm{Cd},{ }^{134} \mathrm{Cs}$, and ${ }^{241} \mathrm{Am}$, no significant contamination through sea water was detected in the control echinoids.

Loss kinetics of ${ }^{109} \mathrm{Cd},{ }^{134} \mathrm{Cs}$, and ${ }^{241} \mathrm{Am}$ followed a single component exponential model and were characterized by quite short $T_{b 1 / 2}(1.0$ to $1.2 \mathrm{~d})$ (Table 6). Loss kinetics of ${ }^{65} \mathrm{Zn}$ and $110 \mathrm{~m}$ Ag were more accurately described by a 2-component model (Table 6). The short-lived components of loss represented the major fraction (93 and $67 \%$, respectively) of the total radioactivity in whole echinoids, and were characterized by short $T_{\mathrm{b} 1 / 2 \mathrm{~s}}$ (0.9 and $1 \mathrm{~d}$, respectively). The longlived components of ${ }^{65} \mathrm{Zn}$ and ${ }^{110 \mathrm{~m}} \mathrm{Ag}$ loss kinetics displayed depuration rate constants $\left(\lambda_{1}\right)$ which were virtually equal to zero, thus resulting in infinite $\mathrm{T}_{\mathrm{b} 1 / 21}$. This indicates that $9 \%$ of the ${ }^{65} \mathrm{Zn}$ and $34 \%$ of the ${ }^{110 \mathrm{~m}} \mathrm{Ag}$ activities present
A. ${ }^{65} \mathrm{Zn}$

Remaining actıvity (\%)

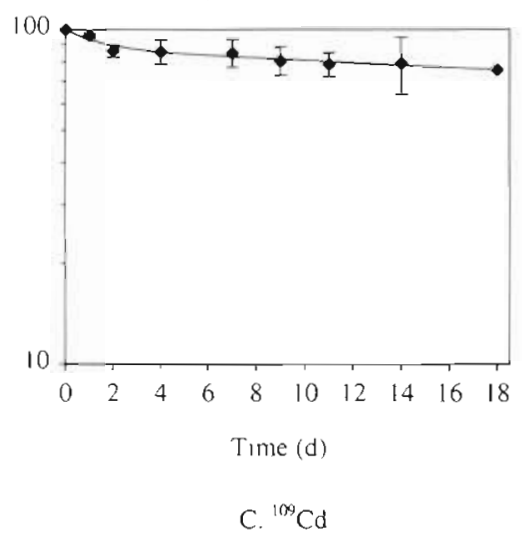

Remaining activity (\%)

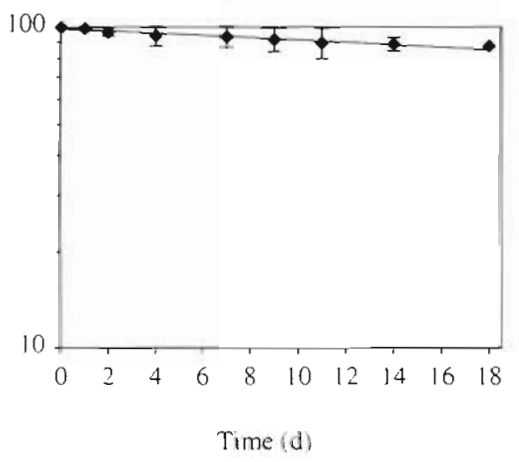

E. ${ }^{241} \mathrm{Am}$

Remainnng actrvity (\%)

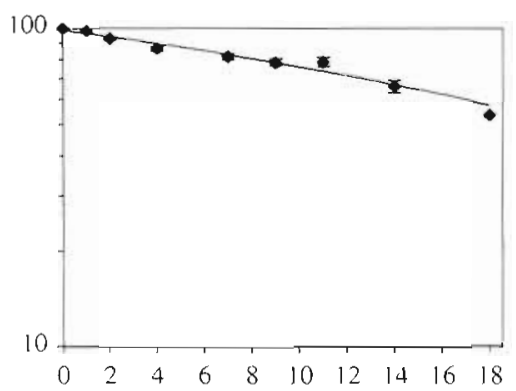

Time (d)

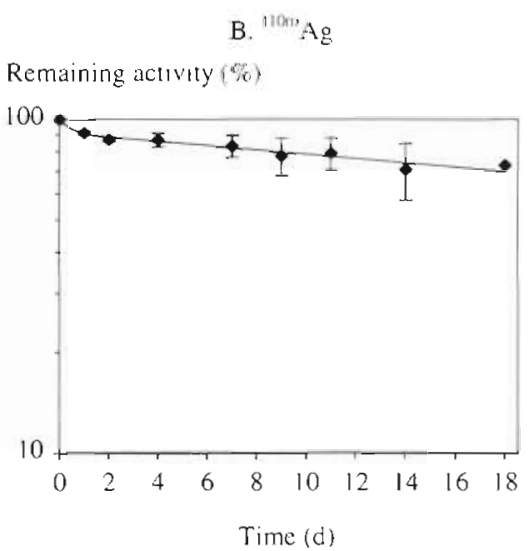

D. ${ }^{134} \mathrm{Cs}$

Remaining activity $(\%)$

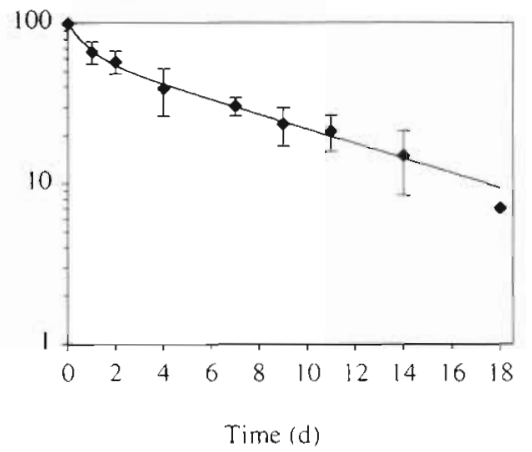

Fig. 2. Paracentrotus lividus. Loss of ${ }^{6.5} \mathrm{Zn},{ }^{110 \mathrm{~m}} \mathrm{Ag},{ }^{109} \mathrm{Cd},{ }^{134} \mathrm{Cs}$, and ${ }^{241} \mathrm{Am}$ in whole echinoids previously exposed to radiotracers for $28 \mathrm{~d}$ in sea water (mean \% remainIng activity $\pm \mathrm{SD}, \mathrm{n}=3$ except for Day 18 when $n=1$ ). Parameters of the equations fitting the data are given in Table 4

Table 6. Paracentrotus lividus. Parameters and statistics of the equations describing the loss kınetics of ${ }^{65} \mathrm{Zn},{ }^{110 \mathrm{~m}} \mathrm{Ag},{ }^{109} \mathrm{Cd}$, ${ }^{134} \mathrm{Cs}$, and ${ }^{24} \mathrm{Am}$ ingested by echinoids during an overnight feeding on Posidonia oceanica leaves. $O$ (single-component loss model): $A_{t}=A_{0} \mathrm{e}^{-\lambda t} ; \mathrm{T}\left(2-\right.$ component loss model): $A_{t}=A_{0 \mathrm{~s}} \mathrm{e}^{-\lambda_{s} t}+A_{01} \mathrm{e}^{-\lambda, t}$

\begin{tabular}{|c|c|c|c|c|c|c|c|c|c|}
\hline & Model & $A_{0 \mathrm{~s}}$ (ASE) & $\lambda_{S}(\mathrm{ASE})$ & $\mathrm{T}_{\mathrm{b} 1 / 2 \mathrm{~s}}$ & $A_{01}(\mathrm{ASE})$ & $\lambda_{1}$ (ASE) & $T_{\mathrm{b} 1 / 2 \mathrm{l}}$ & $\mathrm{R}^{2}$ & $p$ \\
\hline${ }^{65} \mathrm{Zn}$ & $\mathrm{T}$ & $92.5(12.2)$ & $0.671(0.196)$ & 1.03 & $9.4(8.3)$ & $0.000(0.033)$ & $\infty$ & 0.71 & $<0.0001$ \\
\hline $110 \mathrm{~m} / 1$ & $\mathrm{~T}$ & $67.2(7.6)$ & $0.778(0.192)$ & 0.89 & $34.3(4.8)$ & $0.000(0.009)$ & $\infty$ & 0.77 & $<0.0001$ \\
\hline${ }^{109} \mathrm{Cd}$ & 0 & $99.7(7.7)$ & $0.643(0.104)$ & 1.08 & & & & 0.80 & $<0.0001$ \\
\hline${ }^{134} \mathrm{Cs}$ & $\mathrm{O}$ & $95.7(8.5)$ & $0.671(0.139)$ & 1.03 & & & & 0.74 & $<0.0001$ \\
\hline${ }^{241} \mathrm{Am}$ & 0 & $100.0(11.7)$ & $0.596(0.145)$ & 1.16 & & & & 0.64 & $<0.0001$ \\
\hline
\end{tabular}




\section{A. ${ }^{65} \mathrm{Zn}$}

Remaining activity (\%)

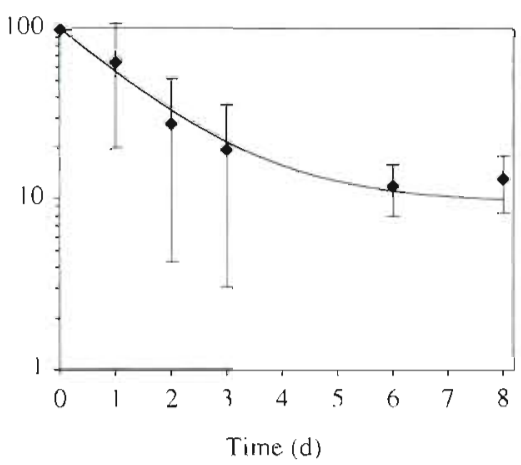

C. ${ }^{109} \mathrm{Cd}$

Remaining activity (\%)

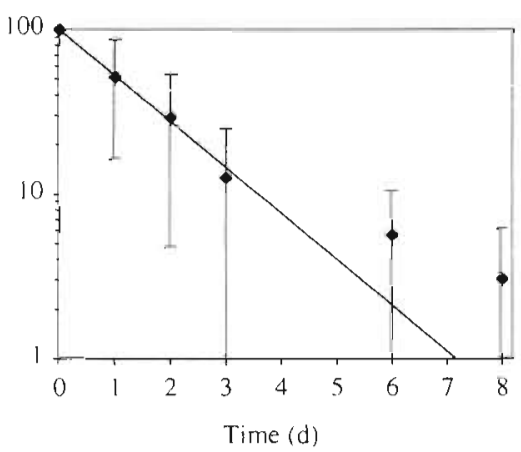

E. ${ }^{231}$ Am

Remaining activity (\%)

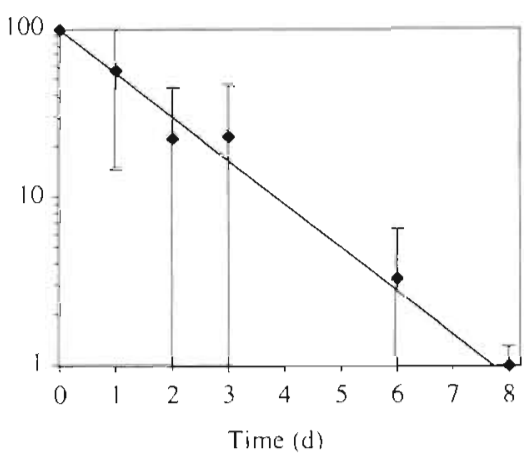

$$
\text { B. }{ }^{1100 \mathrm{Ag}} \mathrm{Ag}
$$

Remaining activity $(\%)$

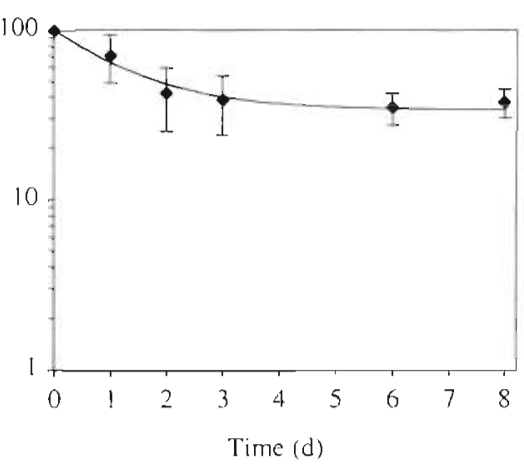

D. ${ }^{124} \mathrm{C}$

Remaining activity (\%)

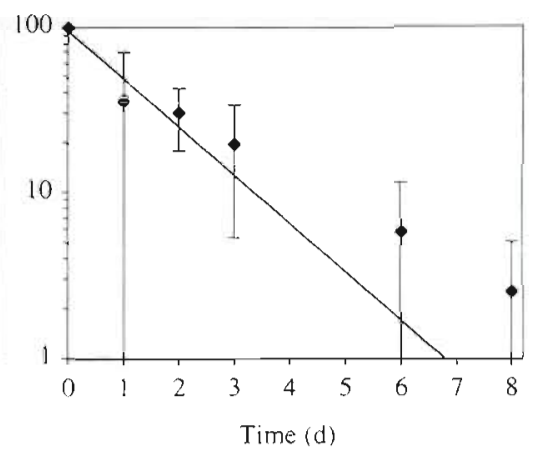

Fig. 3. Paracentrotus lividus. Loss of ${ }^{65} \mathrm{Zn},{ }^{110 \mathrm{~m}} \mathrm{Ag},{ }^{109} \mathrm{Cd},{ }^{134} \mathrm{Cs}$, and ${ }^{241} \mathrm{Am}$ in whole echinoids previously fed overnight on radiolabelled Posidonia oceanica leaves (mean \% remaining activity $\pm \mathrm{SD}, \mathrm{n}=5$ ). Parameters of the equations fitting the data are given in Table 6 in the food ingested are irreversibly incorporated in Paracentrotus lividus.

Eight days after ingestion of the radiolabelled food, the distribution of the remaining radioactivity between the echinoid body compartments was determined (Table 7). Similar to the whole-body data, the percentages presented in Table 7 have been corrected for interference due to contamination from radiotracer recycling when appropriate. The highest proportions of each radiotracer were retained in the digestive wall (from 47 to $79 \%$ ) and in the body wall (from 15 to $47 \%$ ). However, the data for ${ }^{109} \mathrm{Cd},{ }^{134} \mathrm{Cs}$, and ${ }^{241} \mathrm{Am}$ should be viewed with caution, since the activities of those 3 radiotracers were very low at the end of the experiment and, consequently, accuracy in quantifying radioactivity was poor. This is also evident from the high coefficients of variation (from 43 to $200 \%$ ) associated with the mean percentages in the different echinoid compartments (Table 7).

\section{DISCUSSION}

The biokinetic experiments were performed using carrier-free radiotracers $(\mathrm{Zn}, \mathrm{Cd})$ or tracers of high specific activity (Ag, $\left.{ }^{134} \mathrm{Cs},{ }^{241} \mathrm{Am}\right)$ and, except for ${ }^{241} \mathrm{Am}$, which has no stable element, the procedure was designed so that contaminant concentrations added to the experimental water were much lower than the concentrations commonly found in the marine environment. Using extremely low added contaminant concentrations allows the

Table 7. Paracentrotus lividus. Radiotracer distribution (mean $\% \pm \mathrm{SD}, \mathrm{n}=5$ ) between the different body compartments of echinoids fed overnight on radiolabelled food (Posidonia oceanica leaves) and then allowed to ingest uncontaminated food for $8 \mathrm{~d}$

\begin{tabular}{|lrrrrc|}
\hline Compartment & \multicolumn{1}{c}{${ }^{65} \mathrm{Zn}$} & ${ }^{110 \mathrm{~m}} \mathrm{Ag}$ & ${ }^{109} \mathrm{Cd}$ & ${ }^{134} \mathrm{Cs}$ & ${ }^{261} \mathrm{Am}$ \\
\hline Body wall & $20.9 \pm 3.3$ & $15.1 \pm 8.1$ & $46.6 \pm 34.3$ & $27.1 \pm 31.9$ & $20.2 \pm 26.6$ \\
Aristotle's lantern & $2.3 \pm 3.8$ & $0.9 \pm 0.7$ & $0.0 \pm 0.0$ & $5.2 \pm 10.4$ & $0.3 \pm 0.6$ \\
Digestive wall & $69.8 \pm 6.7$ & $79.0 \pm 8.2$ & $47.1 \pm 38.0$ & $53.0 \pm 31.7$ & $70.1 \pm 30.4$ \\
Gonads & $1.7 \pm 3.5$ & $0.4 \pm 0.6$ & $0.0 \pm 0.0$ & $0.0 \pm 0.0$ & $0.0 \pm 0.0$ \\
Coelomic fluid & $5.3 \pm 1.7$ & $4.5 \pm 1.9$ & $6.2 \pm 4.8$ & $14.7 \pm 22.3$ & $9.4 \pm 16.0$ \\
\hline
\end{tabular}


assumption that the metabolism of one element in the organism will not be perturbed by the presence of other elements. Consequently, the advantage of this multi-tracer technique is that several elements may be studied simultaneously, presumably without inter-element interference.

In general, the elements were accumulated efficiently from water by Paracentrotus lividus, with $C F$ ranging from 25 to 200 after a 28 d exposure period. The only exception was ${ }^{134} \mathrm{Cs}$ which was bioaccumulated with a $C F_{\text {equil }}$ of 2.7 . Steady state was reached with ${ }^{134} \mathrm{Cs}$ and tended to be reached with $\mathrm{Zn}, \mathrm{Cd}$, and ${ }^{241} \mathrm{Am}$. In contrast Ag was linearly accumulated during the time course of the experiment, suggesting that a steady state in uptake would take a very long time to reach under natural conditions. After restoration of uncontaminated conditions, the elements were released following a linear $\left(\mathrm{Cd},{ }^{241} \mathrm{Am}\right)$ or a 2-component loss model ( $\mathrm{Zn}, \mathrm{Ag},{ }^{134} \mathrm{Cs}$ ). The whole-body loss of those elements was relatively slow, except for ${ }^{134} \mathrm{Cs}$, which was rapidly lost with an estimated $\mathrm{T}_{\mathrm{b} 1 / 2}$ for the long-lived component of $6.5 \mathrm{~d}$.

Among the body compartments of Paracentrotus lividus, the digestive wall displayed the highest $C F$ for most elements. The only exception was ${ }^{241} \mathrm{Am}$, which was concentrated to a similar degree by the digestive wall and the body wall. In terms of relative distribution, ca $95 \%$ of the total ${ }^{241} \mathrm{Am}$ activity were associated with the echinoid body wall. This predominant distribution of ${ }^{241} \mathrm{Am}$ in the body wall could be due to the particular affinity of the transuranium nuclides for the calcitic endoskeleton which constitutes ca $90 \%$ of the echinoid body wall dry weight. Several authors have shown that the major fraction of those radionuclides is always located in the body wall of echinoderms exposed to the contaminant in sea water (Grillo et al. 1981, Guary et al. 1982, Fowler \& Carvalho 1985). Furthermore, Fowler \& Carvalho (1985) demonstrated a positive correlation between the ${ }^{241} \mathrm{Am}$ CF in different echinoderm species and the proportion of calcitic endoskeleton in the body walls of those species.

Following contamination of the echinoids through the food chain, loss kinetics of $\mathrm{Cd},{ }^{134} \mathrm{Cs}$, and ${ }^{241} \mathrm{Am}$ can be described by a single-component exponential model. Those 3 elements were characterized by a very short turnover time $\left(\mathrm{T}_{\mathrm{b} 1 / 2}=1.03\right.$ to $\left.1.16 \mathrm{~d}\right)$, suggesting that their loss rate is determined mainly by the gut transit of contaminated food. Indeed, mean gut-residence times in Paracentrotus lividus range between 20 and $60 \mathrm{~h}$; total gut-clearance of ingested material may take about 5 d (Lawrence et al. 1989). Hence, Cd, ${ }^{134} \mathrm{Cs}$, and ${ }^{241} \mathrm{Am}$ would not be absorbed to any significant extent from food during the gut transit, and would be entirely lost with faeces within a few days after their ingestion with food.
In the case of $\mathrm{Zn}$ and $\mathrm{Ag}$, the loss kinetics were best described by a 2-component exponential model. The major fraction of the $\mathrm{Zn}$ and Ag ingested (93 and 67\%, respectively) was lost with a short-lived component whose $T_{b 1 / 2 s}$ averaged only $1 \mathrm{~d}$. Most probably, this component represents the large, unassimilated fraction of $\mathrm{Zn}$ and $\mathrm{Ag}$ which is readily lost through defecation. Examination of the parameters of the long-lived loss component indicates that 9 and $34 \%$ of the $\mathrm{Zn}$ and Ag, respectively, ingested with food may be considered as having been actually assimilated into the tissues of Paracentrotus lividus. The assimilated fractions of $\mathrm{Zn}$ and $\mathrm{Ag}$ were strongly retained by $P$. lividus during the time course of the experiment (estimated $T_{\text {b1/2l }}=\infty$ ), most particularly in the echinoid digestive wall, which retained respectively 70 and $80 \%$ of the total $\mathrm{Zn}$ and Ag body burdens. Nevertheless, the depuration experiment was carried out for only $8 d$, and extrapolation to longer periods of time would have to be further supported by longer experiments.

In the case of $\mathrm{Zn}$, which is a well-known essential element, the long retention time of the assimilated fraction most probably results from the incorporation of this element into numerous constituents of the cells, since more than $200 \mathrm{Zn}$ enzymes and proteins have been identified in living organisms (Hambidge et al. 1986)

The particularly high retention efficiency for Ag might be explained by the occurrence of an Ag detoxification process which would consist of the immobilization of $\mathrm{Ag}$ in a stable, detoxified form. Such a process is well known to occur in different bivalve species. Indeed, Pectinidae and Ostreidae accumulate high levels of Ag in their soft tissues, an important fraction of which is stored as $\mathrm{Ag}_{2} \mathrm{~S}$, a very stable compound whose toxicity is therefore limited (see e.g Martoja et al. 1988, 1989, Berthet et al. 1990, 1992). This detoxified form of $\mathrm{Ag}$ is lost very slowly, and it remains sequestered in the basement membranes of most organs of the bivalves for very long periods without any injury (Berthet et al. 1990, 1992).

Such a detoxification process involving storage of Ag does not appear to have been reported in echinoderms. However, most interestingly, it is well known that certain irregular echinoids such as the spatangoids Brissopsis spp. and Echinocardium spp. store large amounts of Fe as stable, granular deposits of ferric phosphate lying within the connective tissue layer of the large intestine (Buchanan et al. 1980). In Brissopsis lyrifera, it was demonstrated that Fe accumulates with age, the deposit weight accounting for up to $29 \%$ of the dry weight of the large intestine tissues (Buchanan et al. 1980). Similarly, numerous holothuroid species of the family Molpadiidae are known to synthesize amorphous ferric phosphate-rich gran- 
ules that accumulate within the connective tissues of the dermis (Lowenstam \& Rossman 1975, Ofer et al. 1981) Furthermore, in the particular case of Paracentrotus lividus individuals living near the sewage outlet of Marseille, France, accumulations of extracellular rhombohedral crystals containing mainly $\mathrm{Fe}, \mathrm{S}$, and $\mathrm{Cl}$ were observed in the connective tissues of the gut and gonads (Delmas 1989, 1990). Delmas (1989, 1990) hypothesized that the crystalline deposits of $\mathrm{Fe}$ in $P$. lividus were related to the elevated amounts of iron chloride released in the ambient sea water by the sewage treatment plant (ca $250 \mathrm{~kg} \mathrm{~d}^{-1}$ ) emptying into the Marseille outlet.

It is noteworthy that the loss kinetics of $\mathrm{Ag}$ were different between echinoids exposed to the metal through the food and those exposed through sea water, with Ag retention being more efficient after food exposure. These differences are probably due to the fact that loss after uptake from food concerned mainly loss from the digestive wall which contained ca $80 \%$ of the total Ag body burden $8 \mathrm{~d}$ after food ingestion (see Table 7), whereas loss after uptake from sea water concerned mainly loss from the body wall, since this compartment contained 80 to $43 \%$ of the total Ag body burden, depending upon the length of the depuration period (see Table 3). Indeed, the body wall was found to retain Ag less efficiently than the digestive wall. In addition, the differences noted between Ag loss after food or water exposure could also be due to the influence of the exposure mode on the chemical form of $\mathrm{Ag}$ once accumulated in Paracentrotus lividus. It has been shown that pathways of accumulation influence the binding of Ag with intracellular compounds in bivalves. In particular, the fraction of Ag accumulated that is stored as $\mathrm{Ag}_{2} \mathrm{~S}$ is higher in oysters that have accumulated Ag through food (94\%) than from sea water (73\%) (Berthet et al. 1992).

Thus, the results indicate that, with the exception of Ag, Paracentrotus lividus bioaccumulates the elements considered here predominantly through uptake from sea water. Similar conclusions were previously reported for ${ }^{241} \mathrm{Am}, \mathrm{V}$, and $\mathrm{Cd}$ bioconcentration in $P$. Iividus (Guary 1980, Miramand et al. 1982, Warnau et al. $1995 \mathrm{C}$, respectively). In the cases of $\mathrm{Cd},{ }^{134} \mathrm{Cs}$, and ${ }^{241} \mathrm{Am}$, the present study even suggests that water constitutes the sole source for metal uptake in $P$. lividus

Nevertheless, even if metal uptake from food is negligible, care should be taken to provide food to the test organisms throughout the duration of experiments testing uptake from water. Food availability affects the activity of the whole organism and its metabolism (see e.g. Riisgård \& Randløv 1981, Lawrence 1987) and, consequently, this might also influence metal uptake from water. This relationship is quite well documented in the mussel Mytilus edulis whose metal accumulation pattern is dominated by uptake from ambient water while uptake from food plays only an insignificant role (e.g. Dahlgaard 1981, Borchardt 1983, Nolan \& Dahlgaard 1991). Although Dahlgaard (1981) did not note a feeding effect on the accumulation of different metals in $M$. edulis, several authors have demonstrated that Cd uptake from sea water is actually correlated with the quantity of food available (e.g. Borchardt 1983, Riisgård et al. 1987). Moreover, in conditions of acute contamination, it has been shown that elevated $\mathrm{Cd}$ concentration in food can influence $\mathrm{Cd}$ uptake from water by $P$. lividus, even if Cd from food does not contribute significantly to the global uptake of this metal (Warnau et al. 1995c, d).

The characteristic kinetics of the uptake and loss of the elements tested indicate that Paracentrotus lividus, and more particularly its digestive wall and body wall, would readily reveal an environmental contamination by any one of those elements. In addition, except for ${ }^{134} \mathrm{Cs}$, P. lividus could preserve this information over quite a long period (on a time scale of months). Use of this echinoid species as a biomonitor for these metals would thus be particularly relevant, since it constitutes an integrator of the average levels of contamination in its ambient environment. In the case of $\mathrm{Ag}, P$. lividus should be considered as an effective long-term biomonitor (yearly time scales), since a substantial fraction of the metal ingested with food would be taken up and be virtually irreversibly bound in the echinoid tissues. For ${ }^{134} \mathrm{Cs}, P$. lividus may also be considered as a potentially valuable biomonitor, however, only over relatively short-term periods, since the corresponding turnover time in the whole echinoid averaged only a few days.

It is generally recognized that the use of a single species in biomonitoring studies is not ideal from an ecological point of view. It is now widely accepted that the design of a biomonitoring programme should use a set of biotic and abiotic tests, i.e. the so-called Test System concept (e.g. Dinnel et al. 1989, Gray 1989, Chapman 1993). The present work strongly suggests that the use of adult individuals of Paracentrotus lividus in such programmes would be a valuable tool.

Acknowledgements. The IAEA Marine Environment Laboratory operates under a bipartite agreement between the International Atomic Energy Agency and the Government of the Principality of Monaco. We gratefully thank Dr. G. De Becker for fruitful discussions and Mr. R. Gallard for skilful technical assistance. We especially thank the crew of the RV 'Physalie' for their help in sampling. The study was partially supported by a European Science Foundation Research Fellowship (RF/94/53/E) and a FRIA Research Grant (ref. 910528) to M.W., and by funds from the 'Fondation Louis Henry' a.s.b.l. This is a contribution of the 'Centre Interuniversitaire de Biologie Marine' (CIBIM). 


\section{LITERATURE CITED}

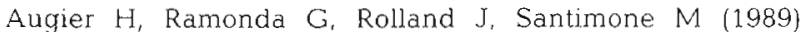
Teneurs en métaux lourds des oursins comestibles Paracentrotus lividus (Lamarck) prélevés dans quatre secteurs tests du littoral de Marseille (Méditerranée, France). Vie Marine 10 HS: 226-239

Bay D (1984) A field study of the growth dynamics and productivity of Posidonia oceanica (L.) Delile in Calvi Bay, Corsica. Aquat Bot 20:43-64

Bayne BL, Clarke KR, Gray JS (1988) Biological effects of pollutants: results of a practical workshop. Mar Ecol Prog Ser 46

Berthet B, Amiard JC. Amiard-Triquet C, Martoja R, Jeantet AY (1992) Bioaccumulation, toxicity and physico-chemical speciation of silver in bivalve molluscs: ecotoxicological and health consequences. Sci Total Environ 125:97-122

Berthet B, Amiard-Triquet C, Martoja R (1990) Effets chimiques et histologiques de la décontamination de l'huitre Crassostrea gigas Thunberg préalablement exposée à l'argent. Water Air Soil Pollut 50:355-369

Borchardt T (1983) lnfluence of food quantity on the kinetics of cadmium uptake and loss via food and seawater in Mytilus edulis. Mar Biol 76:67-76

Borchardt T, Burchert S, Karbe L, Zeitnier R (1989) Enhanced heavy metal concentrations in Mytilus edulis from the central North Sea. In: Ros JD (ed) Topics in marine biology. Sci Mar 53:725-728

Brown DG, Lanno RP, van den Heuvel MR, Dixon DG (1995) HPLC determination of plasma thiocyanate concentrations in fish blood: application to laboratory pharmacokinetic and field-monitoring studies. Ecotoxicol Environ Saf 30:302-308

Bruland KD (1983) Trace elements in seawater. In: Riley JP, Chester R (eds) Chemical oceanography 8. Academic Press, London, p 157-200

Bryan GW (1984) Pollution due to heavy metals and their compounds. In: Kinne O (ed) Marine ecology, Vol 5, Part 3 John Wiley and Sons Ltd, Chichester, p 1289-1431

Buchanan JB, Brown BE, Coombs TL, Pirie BJS, Allen JA (1980) The accumulation of ferric iron in the guts of some spatangoid echinoderms. J Mar Biol Ass UK 60:631-640

Catsiki VA, Katsilieri C, Gialamas V (1994) Chromium distribution in benthic species from a gulf receiving tannery wastes (Gulf of Geras - Lesbos Island, Greece). Sci Total Environ 145:173-185

Chapman PM (1993) The role of ecotoxicology in environmental impact assessment. Environ Profes 15:139-144

Clark RB (1986) Marine pollution. Clarendon Press, Oxford

Dahlgaard H (1981) Bioindicators for monitoring radioactive pollution of the marine environment-experiments on the feasibility of Mytilus as a bioindicator in estuarine environments with some comparisons to Fucus. Riso Reports 15. Risø, Roskilde, Denmark

Dance C (1987) Patterns of activity of the sea urchin Paracentrotus lividus in the Bay of Port-Cros (Var, France, Mediterranean). PSZN I Mar Ecol 8:131-142

Delmas Ph (1989) Bioaccumulations de cristaux de fer dans les gonades et le tube digestif de Paracentrotus lividus (Lam.) soumis à l'influence d'une pollution à dominante domestique. Vie Marine $10 \mathrm{HS}$ : 240-247

Delmas Ph (1990) Etude ultrastructurale de bioaccumulations de cristaux de fer dans les gonades de l'échinoïde Paracentrotus lividus (Lam.) soumis à des rejets de chlorure ferrique. C R Acad Sci Paris 311:69-74

Dinnel PA, Link JM, Stober QJ, Letourneau MW, Roberts WE (1989) Comparative sensitivity of sea urchin sperm bio- assays to metals and pesticides. Arch Environ Contam Toxicol 18:748-755

Fisher NS, Nolan CV, Fowler SW (1991) Scavenging and retention of metals by zooplankton fecal pellets and marine snow. Deep Sea Res 38:1261-1275

Fowler SW, Carvalho FP (1985) Americium biokinetics in benthic organisms as a function of feeding mode. Bull Environ Contam Toxicol 35:826-834

Fowler SW, Guary JC (1977) High absorption efficiency for ingested plutonium in crabs. Nature 266:827-828

Fowler SW, Oregioni B (1976) Trace metals in mussels from the NW Mediterranean. Mar Pollut Bull 7:26-29

Gray JS (1989) Do bioassays adequately predict ecologica! effects of pollutants? Hydrobiologia 188/189:397-402

Grillo MC, Guary JC, Fowler SW (1981) Comparative studies on transuranium nuclide biokinetics in sediment-dwelling invertebrates. In: Impacts of radionuclide releases into the marine environment. IAEA Publ, Vienna, p 273-291

Guary JC (1980) Recherches sur les transferts et la fixation du plutonium, de l'americium et du neptunium dans le milieu marin. PhD thesis, Université d'Aix-Marseille II

Guary JC, Fowler SW, Beasley TM (1982) Routes of plutonium uptake and their relation to biomagnification in starfish. Mar Pollut Bull 13:99-102

Hambidge KM, Casey CE, Krebs NF (1986) Zinc, In: Mertz W (ed) Trace elements in human and animal nutrition, Vol 2, 5 th edn. Academic Press, Orlando, FL

Haug A, Melsom S, Omang S (1974) Estimation of heavy metal pollution in two Norwegian fjord areas by analysis of the brown alga Ascophylum nodosum. Environ Pollut 7 : $173-193$

Hayward PJ, Ryland JS (1990) The marine fauna of the British Isles and north-west Europe, Vol 2. Clarendon Press, Oxford

Hubbell SP, Sikora A, Paris OH (1965) Radiotracer, gravimetric and calorimetric studies of ingestion and assimilation rates of an isopod. Health Phys 11:1485-1501

Hutchins DA, Teyssié JL, Boisson F, Fowler SW, Fisher NS (1996) Temperature effect on uptake and retention of contaminant radionuclides and trace metals by the brittle star Ophiothrix fragilis. Mar Environ Res 41:363-378

Kuroshima R, Kimura S, Date K, Yamamoto Y (1993) Kinetic analysis of cadmium toxicity to red sea bream, Pagrus major. Ecotoxicol Environ Saf 25:300-314

Lawrence JM (1987) A functional biology of echinoderms. Croom Helm Ltd, London

Lawrence JM, Régis MB, Delmas Ph, Gras G, Klinger I (1989) The effect of quality of food on feeding and digestion in Paracentrotus lividus (Lamarck) (Echinodermata: Echinoidea). Mar Behav Physiol 15:137-144

Lowenstam HA, Rossman GR (1975) Amorphous, hydrous, ferric phosphatic dermal granules in Molpadia (Holothuroidea): physical and chemical characterization and ecologic implications of the bionorganic fraction. Chem Geol 15:15-51

Martoja M, Truchet M, Berthet B (1989) Effets de la contamination expérimentale par l'argent chez Chlamys varia $\mathrm{L}$. (Bivalve Pectinidé). Données quantitatives, histologiques et microanalytiques. Ann Inst Océanogr 65:1-13

Martoja R, Ballan-Dufrançais C, Jeantet AY, Gouzerh P, Amiard JC, Amiard-Triquet C, Berthet B, Baud JP (1988) Effets chimiques et cytologiques de la contamination expérimentale de l'huitre Crassostrea gigas Thunberg par l'argent administré sous forme dissoute ou par voie alimentaire. Can J Fish Aquat Sci 45:1827-1841

Miramand P, Fowler SW, Guary JC (1982) Comparative study of vanadium biokinetics in three species of echinoderms. Mar Biol 67:127-134 
Nakamura R, Nakahara M, Suzuki Y. Ueda T (1986) Relative importance of food and water in the accumulation of radionuclides by sea urchin Strongylocentrotus nudus. Bull Jap Soc Scient Fish 52:703-710

Nedelec $H$, Verlaque M (1984) Alimentation de l'oursin Paracentrotus lividus (Lamarck) dans un herbier à Posidonia oceanica (L.) Delile en Corse (Méditerranée-France). In: Boudouresque CF, Jeudy de Grissac A. Olivier J (eds) International workshop on Posidonia beds, Vol 1 GIS Posidonie Publ, Marseille, p 349-364

Nolan C, Dahlgaard H (1991) Accumulation of metal radiotracers by Mytilus edulis. Mar Ecol Prog Ser 70:165-174

O'Connor TP, Cantillo AY, Lauenstein GG (1994) Monitoring of temporal trends in chemical contamination by the NOAA National Status and Trends Mussel Watch Project. In: Kramer KJM (ed) Biomonitoring of coastal waters and estuanes. CRC Press, Boca Raton, FL, p 29-50

Ofer S, Papaefthymiou GC, Frankel RB, Lowenstam HA (1981) Mössbauer spectroscopy of iron-containing dermal granules from Molpadia intermedia. Biochem Biophys Acta 676:199-204

Ott JA (1980) Growth and production in Posidonja oceanica (L.) Delile. PSZN I Mar Ecol 1:47-64

Ott JA (1981) Adaptative strategies at the ecosystem level: examples from two benthic marine systems. PSZN I Mar Ecol 2:113-158

Papadopoulou C, Kanias GD, Moraitopoulou-Kassimati E (1976) Stable element of radioecological importance in certain echinoderm species. Mar Pollut Bull 7:143-144

Phillips DJH (1976) The common mussel Mytilus edulss as an indicator of pollution by zinc, cadmium, lead and copper. I. Effects of environmental variables on uptake of metals. Mar Biol 38:59-69

Phillips DJH (1990) Use of macroalgae and invertebrates as monitors of metal levels in estuaries and coastal waters. In: Furness RW, Rainbow PS (eds) Heavy metals in the marine environment. CRC Press, Boca Raton, FL, p 81-99

Reichle DE (1967) Radioisotope turnover and energy flow in terrestrial isopod populations. Ecology 48:351-366

Reichle DE, Dunaway PB, Nelson DJ (1970) Turnover and

This article was submitted to the editor concentration of radionuclides in food chains. Nucl Saf 11 $43-55$

Riisgård HU, Bjornestad E, Mohlenberg F (1987) Accumulation of cadmium in the mussel Mytilus edulis: kinetics and importance of uptake via food and sea water. Mar Biol 96 $349-353$

Riisgård HU, Randlov A (1981) Energy budgets, growth and filtration rates in Mytilus edulis at different algal concentrations. Mar Biol 61:227-234

Sheppard CRC, Bellamy DJ (1974) Pollution of the Mediterranean around Naples. Mar Pollut Bull 5:42-44

Stebbing ARD, Dethlefsen V, Carr M (1992) Biological effects of contaminants in the North Sea. Mar Ecol Prog Ser 91

Warnau M, Ledent $G$, Temara A, Alva V, Jangoux M, Dubois $\mathrm{Ph}$ (1995a) Allometry of heavy metal bioconccntration in the echinoid Paracentrotus lividus (Echinodermata). Arch Environ Contam Toxicol 29:393-399

Warnau $M$, Ledent $G$, Temara A, Bouquegneau JM, Jangoux M, Dubois Ph (1995b) Heavy metals in Posidonia oceanica and Paracentrotus lividus from seagrass beds of northwestern Mediterranean. Sci Total Environ 171:95-99

Warnau $M$, Ledent $G$, Temara $A$, Jangoux $M$, Dubois $P h$ (1995c) Experimental cadmium contanination of the echinoid Paracentrotus lividus: influence of exposure mode and distribution of the metal in the organism. Mar Ecol Prog Ser 116:117-124

Warnau M, Teyssié JL, Fowler SW (1995d) Effect of feeding on cadmium bioaccumulation in the echinoid Paracentrotus lividus (Echinodermata). Mar Ecol Prog Ser 126: 305-309

Warnau M. Teyssié JL, Fowler SW (in press) Cadmium bioconcentration in the echinoid Paracentrotus lividus: influence of the cadmium concentration in sea water. Mar Environ Res

Whicker FW, Schultz V (1982) Radioecology: nuclear energy and the environment, Vol 2. CRC Press, Boca Raton, FL

Wilkinson L (1988) Systat: the system for statistics. Systat Inc, Evanston, IL

Zar JH (1984) Biostatistical analysis, 2nd edn. Prentıce-Hall, Englewood Cliffs, NJ

Manuscnpt first received: December 27, 1995

Revised version accepted: June 25, 1996 